\title{
Taxonomic Notes: Synonymy of Enterobacter cancerogenus (Urošević 1966) Dickey and Zumoff 1988 and Enterobacter taylorae Farmer et al. 1985 and Resolution of an Ambiguity in the Biochemical Profile
}

\author{
H. C. SCHØNHEYDER, ${ }^{1 *}$ K. T. JENSEN, ${ }^{2}$ AND W. FREDERIKSEN ${ }^{3}$ \\ Department of Clinical Microbiology, Aalborg Hospital, DK-9000 Aalborg, ${ }^{1}$ Department of Clinical \\ Microbiology, Esbjerg Hospital, DK-6700 Esbjerg, ${ }^{2}$ and Department of Clinical Microbiology, \\ Statens Seruminstitut, DK-2300 Copenhagen $S{ }^{3}$ Denmark
}

\begin{abstract}
The descriptions of Enterobacter taylorae and Enterobacter cancerogenus show differences in key reactions (ornithine decarboxylase and D-sorbitol fermentation) that have not received attention and are inconsistent with the synonymy proposed by Grimont and Ageron (P. A. D. Grimont and E. Ageron, Res. Microbiol. 140:459-465, 1989). A reassessment of the biochemical properties confirms that they are synonymous. We believe that the priority of $E$. cancerogenus should be maintained in diagnostic and clinical microbiology even if the epithet could be misunderstood in a clinical setting.
\end{abstract}

In 1985 the name Enterobacter taylorae was proposed by Farmer et al. (2) for isolates related to Enterobacter cloacae that did not ferment saccharose, raffinose, adonitol, myoinositol, or D-sorbitol. However, in 1989 Grimont and Ageron (3) reported that $E$. taylorae and Enterobacter cancerogenus form one genomic group with one biotype. E. taylorae and $E$. cancerogenus were thus considered to be subjective synonyms, with type strains ATCC 35317 and NCPPB 2176, respectively. $E$. cancerogenus had priority according to the International Code of Nomenclature of Bacteria because the epithet cancerogena was published in 1966 (see reference 28 in Dickey and Zumoff [1]); the priority date of the epithet is not affected by the fact that Erwinia cancerogena was later transferred to the genus Enterobacter (1). However, there were unrecognized contradictions in the description of $E$. cancerogenus by Dickey and Zumoff (1). Although a positive reaction for ornithine (and arginine) decarboxylase was mentioned among the arguments for reassessing the relationship of $E$. cancerogena to the genus Enterobacter, a negative ornithine decarboxylase reaction was listed in the description of the species based on three strains, including NCPPB 2176. Moreover, acid from D-sorbitol was given as positive within 7 days. For E. taylorae, the reverse pattern of reactions was stated (3).

We studied the type strains ATCC 35317 and NCPPB 2176 to resolve this ambiguity. Both strains were obtained from two sources (see Table 1). Conventional tests (4) were read for 12 days (Table 1). We could not confirm the negative results for $E$. cancerogenus in the ornithine decarboxylase test given by Dickey and Zumoff (1). Moreover, we found fully concordant biochemical profiles for $E$. cancerogenus and $E$. taylorae (data not shown), thus corroborating the data of Grimont and Ageron (3). Various results for gelatine hydrolysis and lactose fermentation in the literature probably reflect different periods of incubation and/or methodology, as gelatine liquefaction

\footnotetext{
* Corresponding author: Department of Clinical Microbiology, Aalborg Hospital, Hobrovej 18-22, P.O. Box 365, DK-9100 Aalborg, Denmark. Phone: 45-99323207. Fax: 45-99323216.
}

TABLE 1. Comparison of biochemical reactions of type strains for E. cancerogenus and E. taylorae

\begin{tabular}{|c|c|c|c|c|}
\hline \multirow[t]{2}{*}{ Biochemical profile } & \multicolumn{2}{|c|}{$\begin{array}{l}\text { E. cancerogenus } \\
\text { NCPPB } 2176^{\mathbf{T}} \\
\text { from source }^{a} \text { : }\end{array}$} & \multicolumn{2}{|c|}{$\begin{array}{c}\text { E. taylorae CDC } \\
2126-81(=\text { ATCC } \\
\left.35317^{\mathrm{T}}\right) \text { from } \\
\text { source }^{a}:\end{array}$} \\
\hline & A & $\begin{array}{c}\text { B } \\
\text { (CCUG 25231) }\end{array}$ & A & $\begin{array}{c}\mathrm{B} \\
\text { (CCUG 18765) }\end{array}$ \\
\hline $\begin{array}{l}\text { Ornithine decarboxylase } \\
(\text { (Møller })^{b}\end{array}$ & + & + & + & + \\
\hline $\begin{array}{l}\text { Arginine dihydrolase } \\
\text { (Møller) }\end{array}$ & + & + & + & + \\
\hline Gelatine hydrolysis $^{c}$ & 0 & + & + & + \\
\hline $\begin{array}{l}\text { Gelatine hydrolysis } \\
\text { (Kohn-Lautrop) }\end{array}$ & 0 & + & + & + \\
\hline Acid from lactose $^{d}$ & + & + & + & + \\
\hline Acid from D-sorbitol ${ }^{e}$ & 0 & 0 & 0 & 0 \\
\hline
\end{tabular}

${ }^{a}$ A, type strain obtained through the courtesy of F. Grimont, Institut Pasteur, Paris, France; B, type strain obtained from Jan Ursing, University of Lund, Malmø, Sweden. A zero indicates a negative reaction.

${ }^{b}$ Negative reaction reported for E. cancerogenus by Dickey and Zumoff (1).

${ }^{c}$ Negative reaction reported by Farmer et al. (2).

${ }^{d}$ Negative reaction reported by Grimont and Ageron (3); late acidification in accordance with Farmer et al. (2).

${ }^{e}$ Positive reaction reported for E. cancerogenus by Dickey and Zumoff (1); $10 \%$ positive by day 7 according to Farmer et al. (2).

occurred after 12 days (three of four tests) and lactose fermentation occurred after 5 days (four of four tests).

The DNA-DNA homology findings of Grimont and Ageron (3) have been corroborated by Sakazaki (6), and there seems to be no doubt that $E$. cancerogenus and $E$. taylorae belong to the same species. Although E. cancerogenus is a rare clinical isolate $(2,5)$, the priority of the epithet cancerogenus will logically lead to reporting of $E$. cancerogenus in specimens from patients. Even if the epithet could be misunderstood in a clinical setting, E. cancerogenus could not be considered a nomen periculosum. Usage has not been consistent in recent publications (5). Therefore, we recommend that the priority of 
the epithet cancerogenus be observed for communications in the field of diagnostic and clinical microbiology.

\section{REFERENCES}

1. Dickey, R. S., and C. H. Zumoff. 1988. Emended description of Enterobacter cancerogenus comb. nov. (formerly Erwinia cancerogena). Int. J. Syst. Bacteriol. 38:371-374.

2. Farmer, J. J., III, G. R. Fanning, B. R. Davis, C. M. O'Hara, C. Riddle, F. W. Hickman-Brenner, M. A. Asbury, V. A. Lowery, III, and D. J. Brenner. 1985. Escherichia fergusonii and Enterobacter taylorae, two new species of Enterobacteriaceae isolated from clinical specimens. J. Clin. Microbiol. 21:77-81.

3. Grimont, P. A. D., and E. Ageron. 1989. Enterobacter cancerogenus (Urošević, 1966) Dickey and Zumoff 1988, a senior subjective synonym of Enterobacter taylorae Farmer et al. (1985). Res. Microbiol. 140:459-465.

4. Lautrop, H. 1956. Gelatin-liquefying Klebsiella strains (Bacterium oxytocum (Flügge)). Acta Pathol. Microbiol. Scand. 39:375-384.

5. Rubinstien, E. M., P. Klevjer-Anderson, C. A. Smith, M. T. Drouin, and J. E. Patterson. 1993. Enterobacter taylorae, a new opportunistic pathogen: report of four cases. J. Clin. Microbiol. 31:249-254.

6. Sakazaki, R. Personal communication. 